\title{
A ciência nos perfumes: atribuindo significados à química orgânica através da história da temática
}

\author{
Márcia Maria Pinto Coelho ${ }^{1}$ (Escola Estadual Duarte de Abreu) \\ Marlon Duarte Moreira² (UFJF) \\ Andreia Francisco Afonso ${ }^{3}$ (UFJF)
}

\section{RESUMO - RODA DE CONVERSA}

O aprendizado de Química Orgânica, geralmente, está associado à memorização de fórmulas e nomes das diferentes estruturas. Assim, muitos discentes não conseguem reconhecer as substâncias orgânicas que estão no seu cotidiano. Para auxiliar nessa percepção, elaboramos uma intervenção com a temática "Perfume", no terceiro ano do Ensino Médio, de uma escola estadual de Juiz de Fora. Iniciamos, explicando a origem da palavra "Perfume", e como novos aromas foram descobertos, a partir da queima de materiais orgânicos. Discutimos as diversas utilidades das fragrâncias produzidas, como por exemplo, servir de oferenda a deuses cultuados por alguns povos e como os aromas foram sendo incorporados aos costumes da sociedade. Na segunda etapa, apresentamos trechos do filme "Perfume - a história de um assassino" para mostrar o desenvolvimento da ciência, em relação às técnicas de extração dos óleos essenciais em diferentes épocas da História. Para finalizar, disponibilizamos amostras (água, álcool, óleo de girassol, vinagre, essência de cravo e perfume de patchouli) para que os alunos registrassem a fragrância percebida. Através dessa atividade, expomos as fórmulas estruturais das moléculas de cada amostra, associando-as aos grupos funcionais, e descrevemos como as células olfativas captam as essas moléculas de odor - substâncias orgânicas voláteis-, formando a memória olfativa.

\footnotetext{
${ }_{1}^{1}$ Bolsista do subprojeto Química do PIBID/UFJF)

2 Bolsista do subprojeto Química do PIBID/UFJF)

${ }^{3}$ Bolsista do subprojeto Química do PIBID/UFJF)
} 